\title{
Terminology for Achilles tendon related disorders
}

\author{
C. N. van Dijk • M. N. van Sterkenburg • \\ J. I. Wiegerinck $\cdot$ J. Karlsson $\cdot$ N. Maffulli
}

Received: 6 October 2010/ Accepted: 13 December 2010/Published online: 11 January 2011

(c) The Author(s) 2011. This article is published with open access at Springerlink.com

\begin{abstract}
The terminology of Achilles tendon pathology has become inconsistent and confusing throughout the years. For proper research, assessment and treatment, a uniform and clear terminology is necessary. A new terminology is proposed; the definitions hereof encompass the anatomic location, symptoms, clinical findings and histopathology. It comprises the following definitions: Mid-portion Achilles tendinopathy: a clinical syndrome characterized by a combination of pain, swelling and impaired performance. It includes, but is not limited to, the histopathological diagnosis of tendinosis. Achilles paratendinopathy: an acute or chronic inflammation and/or degeneration of the thin membrane around the Achilles tendon. There are clear distinctions between acute paratendinopathy and chronic paratendinopathy, both in symptoms as in histopathology. Insertional Achilles tendinopathy: located at the insertion of the Achilles tendon onto the calcaneus, bone spurs and calcifications in the tendon proper at the insertion site may exist. Retrocalcaneal bursitis: an inflammation of the bursa in the
\end{abstract}

C. N. van Dijk $(\bowtie) \cdot$ M. N. van Sterkenburg · J. I. Wiegerinck Department of Orthopaedic Surgery, Academic Medical Center, University of Amsterdam, G4-262, PO Box 22700,

1100 DE Amsterdam, The Netherlands

e-mail: c.n.vandijk@amc.uva.nl

J. I. Wiegerinck

e-mail: j.i.wiegerinck@amc.uva.nl

J. Karlsson

Department of Orthopaedics, Sahlgrenska University Hospital,

Gothenburg, Sweden

N. Maffulli

Barts and The London School of Medicine and Dentistry, Centre for Sports and Exercise Medicine, Mile End Hospital, Queen Mary University of London, 275 Bancroft Road, London, UK recess between the anterior inferior side of the Achilles tendon and the posterosuperior aspect of the calcaneus (retrocalcaneal recess). Superficial calcaneal bursitis: inflammation of the bursa located between a calcaneal prominence or the Achilles tendon and the skin. Finally, it is suggested that previous terms as Haglund's disease; Haglund's syndrome; Haglund's deformity; pump bump (calcaneus altus; high prow heels; knobbly heels; cucumber heel), are no longer used.

Keywords Achilles paratendinopathy · Insertional tendinopathy · Haglund · Terminology · Tendinosis . Retrocalcaneal bursitis

\section{Introduction}

Overuse injuries of the Achilles tendon can be either insertional or non-insertional. As there is no evidence available for chronic inflammation in patients with "tendinitis", the term tendinosis has been proposed instead [1]. In 1998, Maffulli et al. proposed to use the term "tendinopathy" for the clinical syndrome characterized by a combination of pain, swelling and impaired performance [23]. In Haglund's syndrome, the pain is located at the postero-superior calcaneal prominence. Originally, Haglund described pain in the hindfoot caused by a prominent postero-superior corner of the calcaneus in combination with wearing a rigid low-back shoe $[2,10]$. Today, when using the term Haglund's exostosis, physicians are usually referring to a clinical situation of pain and tenderness at the postero-lateral aspect of the calcaneus, where a calcaneal prominence can often be palpated. This is also known as "pump-bump", with alternative names as calcaneus altus, high prow heels, knobbly heels, and cucumber heel. 
A distinction between Haglund's disease and other conditions such as a superficial Achilles bursitis must be made. Haglund's disease must be differentiated from Haglund's syndrome, which involves a painful swelling of an inflamed retrocalcaneal bursa, sometimes combined with insertional tendinopathy of the Achilles tendon. It must also be distinguished from Haglund's disease, which is the term of osteochondrosis of the accessory navicular bone. No doubt that all this is confusing: in reality, many different names and terms are used in the literature. The purpose of this paper is to propose a terminology which includes the combination of anatomic location, symptoms, clinical findings and pathological changes for each entity.

\section{Historical perspective}

Mid-portion Achilles tendinopathy

Philip Verheyen, a Dutch surgeon, was the first in 1693 to actually name the Achilles tendon after the Greek hero Achilles [16]. Previously, it was known as "tendo magnus of Hippocrates". In 1883, Raynal described the first case of "cellulite peritendineuse of the Achilles tendon" [32]. Other cases of "cellulite peritendineuse" of the Achilles tendon followed shortly $[2,17]$.

In 1905, Schanz was the first to describe a traumatic inflammation of the Achilles tendon: He described a patient who experienced 'a chronic strain' after mountain climbing [36]. He entitled this "tendinitis Achillea traumatica" [36]. The inflammation was presumed to be located in the Achilles tendon itself, instead of the insertion into the calcaneus, contrary to the standard or ideas of the time $[1,34]$.

The terminology has changed more or less constantly, often without any evident scientific reason throughout the 20th century. In 1950, Lipscomb proposed new definitions for inflammatory processes of tendons. He defined "paratendinitis" as an inflammatory process of tendons or portions of tendons without a tendon sheath; "tenosynovitis" was implemented to refer to inflammatory processes of tendons with a sheath. Additionally, he proposed "peritendinitis" as a general term to refer to either "tenosynovitis" or "paratendinitis" [20].

Since the 1970s, increased effort was put in categorising Achilles tendon pathology, related to subgroups. In 1976, Perugia et al. introduced new terminology on inflammatory problems of the Achilles tendon [30]. They based their definitions on histological findings. Perugia et al. differentiated between pure peritendinitis, peritendinitis associated with tendinosis, and pure tendinosis. Peritendinitis was characterised by the presence of inflammation of the peritendinous sheaths, without any pathological changes in the tendon itself. Peritendinitis associated with tendinosis involved degenerative features of the tendon associated with inflammation of the sheaths. Pure tendinosis was said to be characterized by degenerative phenomena exclusively, often associated with foci of osteo-cartilaginous metaplasia. Later in the same year, Puddu et al. published a paper clarifying the new terms introduced by Perugia et al. [30, 31]. Tendinosis implied tendon degeneration, without any clinical or histological signs of intratendinous inflammation.

Throughout the years, the discussion continued on the terminology of the location and on the actual nomenclature of Achilles tendon disorders [9, 39]. It took, however, until 1992 for Clain and Baxter to divide the definitions of Achilles "tendinitis" in insertional and non-insertional [6].

In 1998, Maffulli et al. [23] suggested to change the confusing terminology concerning overuse tendon conditions. They proposed to use the terms "tendinosis" [15], "paratendinitis", and "tendinitis" only after excision biopsy had been examined by a pathologist as these imply specific, histopathologically proven conditions, with inflammatory cells [23]. They advised not to use the aforementioned terms in clinical practice when discussing overuse tendon injuries. The term "partial tear" should be reserved to acute partial tendinous lesions. In fact, this term may be questioned altogether whether it does exist or not. "Achillodynia" is a purely descriptive term, referring to pain in the region of the Achilles tendon [1, 24, 34]. Finally, Maffulli et al. proposed to name the clinical syndrome of pain, swelling (diffuse or localised), and impaired performance as tendinopathy. Depending on the involved tissues, the terms tendinopathy, paratendinopathy, and pantendinopathy should be used [23]. Maffulli et al.'s publication has greatly helped to reduce the confusion in clinical terminology; the proposal was broadly accepted, but it was not, however, implemented universally. Terminology has therefore remained confusing [27, 40].

Pathology around the Achilles tendon insertion

Albert [1] was the first to describe 'Achillodynia' in 1893, but the underlying pathology was not determined, however, [25]. In 1895, Rössler [34] found that the cause of this Achillodynia was an inflammation of the bursa between the insertion of the Achilles tendon and the postero-superior tuberosity of the calcaneus. Three years later, Painter published his histological findings after resection of the post-calcaneal exostosis causing the inflammation of the post-calcaneal bursa [28]. He concluded the exostoses were most probably manifestations of an osteoarthritic process. In Patrick Haglund's opinion, the term Achillodynia was too general, and he divided patients into three groups: 'Achillotendinitis ossificans', 'Bursitis Achillea', and 
children with growth problems of the epiphysis of the calcaneus. In terms of "bursitis Achillea", he noted there were 2 bursae: one located between the calcaneus and the skin (bursa Achillea infero-posterior), and one between the Achilles tendon and the calcaneus (bursa Achillea superoanterior). In his opinion, the superficial bursitis was caused by incorrect shoe-wear for 'Kulturmenschen' (culture people), and the other (deep bursitis) by either acute or chronic trauma. The inferior posterior bursitis had, in his opinion, no clinical relevance, but the superior anterior bursitis, caused by impingement between the Achilles tendon and a bony prominence on the calcaneus caused clinically relevant signs and symptoms. This condition can be treated surgically by resecting the postero-superior bony prominence of the calcaneus in case conservative measures fail [10, 28]. In 1954, the term 'pump bump' arose. Dickinson et al. described the 'pump bump' as an enlargement of the postero-lateral aspect of the heel at the site of the insertion of the Achilles tendon and Achilles tendon bursitis, mostly associated with wearing high heel shoes. When conservative treatment failed, patients were treated surgically by excision of the postero-superior corner of the calcaneus [7].

Until 1982, inflammation of the retro-calcaneal bursa caused by impingement between the anterior aspect of the Achilles tendon and the posterior part of the calcaneus was named retrocalcaneal bursitis. In that year, Pavlov et al. first described the 'Haglund's syndrome', defined as a frequent cause of posterior heel pain, characterized by a painful soft tissue swelling at the level of the Achilles tendon insertion. Using a lateral heel radiograph, they described a prominent calcaneal bursal projection, retrocalcaneal bursitis, thickening of the Achilles tendon, and a convexity of the superficial soft tissues at the level of the Achilles tendon insertion, a 'pump bump' [29]. This is the first publication in which the authors used the name 'Haglund'. Haglund's deformity was then described by Vega et al. as a tender swelling in the region of the Achilles tendon with visible prominence of the postero-lateral aspect of the calcaneus. In their opinion, the superficial Achilles bursa and/or the retrocalcaneal bursa reflected the enlarged prominence. Then, in 1990 and 1991 'analogies' for Haglund's deformity were described: Haglund's syndrome, achillobursitis, achillodynia, and retro-calcaneal bursitis were mentioned [18, 33]. In 1993, Haglund's disease was added to this list [3], although it was earlier described as being an osteochondrosis of the accessory navicular bone (or os tibiale externum) [5, 18, 42].

Sella et al. [38] thought that all these names were confusing, and proposed separate definitions for Haglund's disease, Haglund's syndrome, and Haglund's deformity. Haglund's disease was referred to as osteochondrosis of the accessory navicular; Haglund's deformity as a chronic, sometimes painful distortion of the postero-superior and lateral portion of the calcaneus; and the term Haglund's syndrome was used when symptoms were present with/without the deformity, and may involve the retro-calcaneal bursa as well as the Achilles tendon and the superficial Achilles bursa [38]. This proposal was, however, not commonly adapted, and many publications kept using terms interchangeably [4, 11-13, 19, 21, 22, 26, 37].

In 1998, the Federative Committee on Anatomical Terminology and the International Federation of Associations of Anatomists published a general anatomic terminology [8]. This "Terminologia Anatomica" defines the retrocalcaneal bursa as "bursa tendinis calcanei" and the superficial calcaneal bursa is termed the "bursa subcutanea calcanea" [8].

\section{Proposed terminology for Achilles tendon related disorders}

Examining the evolution of the terminology over the years, the efforts and the struggle are obvious. Some terms represent a disease, some an anatomic location, a pathology, or a generic name. The reasoning behind a change in terminology is unclear; it appears to be largely susceptible to fashion. In the 19th century, the terminology was mainly based on anatomy [1]; later, it was based on histopathology [30]; others have proposed a 'history'-based terminology [3, 29, 38].

Five leading anatomy journals were contacted, and asked for information on which terminology they demanded from their authors. Based on the answers, it can be concluded that, concerning anatomy, there is no such thing as a "standard terminology". Some stated that the authors were expected to use "widely accepted terminology".

The definitions for Achilles tendon disorders should comprise anatomic location, symptoms, clinical findings, and histopathology. The term to represent the entity must be neutral yet descriptive, uniform and clear. The aforementioned lack of consistency should be avoided as much as possible. The following definitions are therefore proposed (Table 1).

\section{Mid-portion Achilles tendinopathy}

Achilles tendinopathy is a clinical syndrome characterized by a combination of pain, swelling and impaired performance. The swelling can be diffuse or localized. Typically, the nodular swelling is located at $2-7 \mathrm{~cm}$ from the insertion onto the calcaneus. This part of the tendon has also been described as the "main body of the Achilles tendon". This 
Table 1 Terminology for Achilles tendon related disorders, including the anatomic location, symptoms, clinical findings histopathology

\begin{tabular}{|c|c|c|c|c|}
\hline Term & Anatomic location & Symptoms & Clinical findings & Histopathology \\
\hline $\begin{array}{l}\text { Mid-portion } \\
\text { Achilles } \\
\text { tendinopathy }\end{array}$ & $\begin{array}{l}2-7 \mathrm{~cm} \text { from the insertion onto } \\
\text { the calcaneus }\end{array}$ & $\begin{array}{l}\text { A combination of pain, } \\
\text { swelling and impaired } \\
\text { performance }\end{array}$ & Diffuse or localized swelling & $\begin{array}{l}\text { Includes, but is not limited to, } \\
\text { the histopathological } \\
\text { diagnosis of tendinosis: } \\
\text { implies histopathological } \\
\text { diagnosis of tendon } \\
\text { degeneration without clinical } \\
\text { or histological signs of } \\
\text { intratendinous inflammation, } \\
\text { not necessarily symptomatic }\end{array}$ \\
\hline
\end{tabular}

Paratendinopathy

Acute $\quad$ Around the mid-portion Achilles tendon

Edema and hyperaemia

Palpable crepitations, swelling

Exercise-induced pain

Around the mid-portion Achilles tendon

Chronic

\section{Insertional Achilles tendinopathy \\ Retrocalcaneal bursitis \\ Insertion of Achilles tendon onto calcaneus, most often with formation of bone spurs and calcifications in tendon proper at insertion site \\ Bursa in the recess between the anterior inferior side of the Achilles tendon and the posterosuperior aspect of the calcaneus (retrocalcaneal recess)}

Bursa located between
calcaneal prominence or the
Achilles tendon and the skin
Pain, stiffness, sometimes a (solid) swelling

Painful swelling superior to calcaneus

Visible, painful, solid swelling postero-lateral calcaneus (often associated with shoes with rigid posterior portion) Crepitations and swelling less
pronounced
Painful tendon insertion at the mid-portion of the posterior aspect of the calcaneus, swelling may be visible and a bony spur may be palpable

Painful soft tissue swelling, medial and lateral to the Achilles tendon at the level of the posterosuperior calcaneus
Edema and hyperaemia of paratenon, with infiltration of inflammatory cells, possibly with production of a fibrinous exudate that fills the space between tendon sheath and tendon

Paratenon thickened as a result of fibrinous exudate, prominent and widespread proliferation of (myo)fibroblasts, formation of new connective tissue and adhesions between tendon, paratenon, and crural fascia

Ossification of enthesial fibrocartilage, and sometimes small tendon tears occurring at tendon-bone junction

Fibro-cartilaginous bursal walls show degeneration and/or calcification, with hypertrophy of the synovial infoldings and accumulation of fluid in the bursa. Alternatively, the bursa may be primarily involved by inflammatory or infectious bursitis due to an inflammatory arthropathy

Visible, painful, solid swelling and discoloration of skin. Most often located at posterolateral calcaneus; sometimes posterior or posteromedial
An acquired adventitious bursa, developing in response to friction. When inflamed, lined tissue and fluid. by hypertrophic synovial

For radiographic findings see Table 2

entity involves isolated pathology of the tendon proper, and includes, but is not limited to, the histopathological diagnosis of tendinosis [23].

Tendinosis implies histopathological diagnosis of tendon degeneration without clinical or histological signs of intratendinous inflammation, and is not necessarily symptomatic [14]. However, it should be kept in mind that, although the histological term 'tendinosis' is also widely used, the essential lesion of tendinopathy is not, strictu sensu, of a degenerative nature: it has the features of a failed healing response, in which the tendon attempts to heal, but, for some reason, including, possibly, continuous inappropriate mechanical stimuli, the healing process appears non-finalised. 
Table 2 Radiologic findings in Achilles tendon disorders

\begin{tabular}{|c|c|c|c|c|}
\hline Term/Imaging & Plain radiography & Ultrasound & CT & MRI \\
\hline $\begin{array}{l}\text { Mid-portion } \\
\text { Achilles } \\
\text { tendinopathy }\end{array}$ & $\begin{array}{l}\text { Deviation of soft tissue } \\
\text { contours is usually present. } \\
\text { In rare cases calcifications } \\
\text { can be found }\end{array}$ & $\begin{array}{l}\text { Tendon larger than normal in } \\
\text { both cross-sectional area and } \\
\text { antero-posterior diameter. } \\
\text { Hypoechoic areas within the } \\
\text { tendon, disruption of fibrillar } \\
\text { pattern, increase in tendon } \\
\text { vascularity (Echo-Doppler) } \\
\text { mainly in ventral } \\
\text { peritendinous area }\end{array}$ & $\begin{array}{l}\text { In case (massive) calcification } \\
\text { are seen on plain } \\
\text { radiography. CT imaging can } \\
\text { be helpful in pre-operative } \\
\text { planning, showing the exact } \\
\text { size and location of the } \\
\text { calcifications. }\end{array}$ & $\begin{array}{l}\text { Fat- saturated } \mathrm{T} 1 \text { or } \mathrm{T} 2 \\
\text { images: fusiform } \\
\text { expansion,central } \\
\text { enhancement consistent } \\
\text { with intratendinous } \\
\text { neovascularization }\end{array}$ \\
\hline \multicolumn{5}{|c|}{ Paratendinopathy } \\
\hline Acute & - & $\begin{array}{l}\text { A normal Achilles tendon with } \\
\text { circumferential } \\
\text { hypoechogenic halo }\end{array}$ & - & $\begin{array}{l}\text { Peripheral enhancement } \\
\text { on fat-saturated } \mathrm{T} 1 \text { or on } \\
\text { T2 images }\end{array}$ \\
\hline Chronic & & $\begin{array}{l}\text { A thickened hypoechoic } \\
\text { paratenon with poorly } \\
\text { defined borders may show as } \\
\text { a sign of peritendinous } \\
\text { adhesions; increase in tendon } \\
\text { vascularity (Echo-Doppler) } \\
\text { mainly in ventral } \\
\text { peritendinous area }\end{array}$ & & \\
\hline $\begin{array}{l}\text { Insertional } \\
\text { Achilles } \\
\text { tendinopathy }\end{array}$ & $\begin{array}{l}\text { May show ossification or a } \\
\text { bone spur at the tendon's } \\
\text { insertion; possibly deviation } \\
\text { of soft tissue contours }\end{array}$ & Calcaneal bony abnormalities & $\begin{array}{l}\text { Bone formation at insertion. } \\
\text { CT scan is indicated mainly } \\
\text { for pre-operative planning. It } \\
\text { shows the exact location and } \\
\text { size of the calcifications and } \\
\text { spurs }\end{array}$ & $\begin{array}{l}\text { Bone formation and/or on } \\
\text { STIR (short tau } \\
\text { inversion recovery) } \\
\text { hyperintense signal at } \\
\text { tendon insertion }\end{array}$ \\
\hline $\begin{array}{l}\text { Retrocalcaneal } \\
\text { bursitis }\end{array}$ & $\begin{array}{l}\text { A postero-superior calcaneal } \\
\text { prominence can be } \\
\text { identified; radio-opacity of } \\
\text { the retrocalcaneal recess; } \\
\text { possibly deviation of soft } \\
\text { tissue contours }\end{array}$ & $\begin{array}{l}\text { Fluid in the retrocalcaneal } \\
\text { area/bursa (hyperechoic) }\end{array}$ & - & $\begin{array}{l}\text { Hyperintense signal in } \\
\text { retrocalcaneal recess on } \\
\text { T2 weighed images }\end{array}$ \\
\hline $\begin{array}{l}\text { Superficial } \\
\text { calcaneal } \\
\text { bursitis }\end{array}$ & $\begin{array}{l}\text { Possibly deviation of soft } \\
\text { tissue contours }\end{array}$ & $\begin{array}{l}\text { Fluid between skin and } \\
\text { Achilles tendon }\end{array}$ & - & $\begin{array}{l}\text { Hyperintense signal } \\
\text { between Achilles tendon } \\
\text { and subcutaneous tissue } \\
\text { on T2 weighed images }\end{array}$ \\
\hline
\end{tabular}

\section{Achilles paratendinopathy}

Paratendinopathy is defined by acute or chronic inflammation and/or degeneration of the thin membrane around the Achilles tendon. Exercise-induced pain and local swelling around the tendon's mid-portion are the most important symptoms.

Histopathologically, acute paratendinopathy is characterized by edema and hyperaemia of the paratenon, with infiltration of inflammatory cells, possibly with production of a fibrinous exudate that fills the space between the tendon sheath and the tendon, causing palpable crepitations on physical examination. In chronic Achilles paratendinopathy, exercise-induced pain is the major symptom, while crepitations and swelling are less pronounced. Histopathologically, the paratenon becomes thickened as a result of fibrinous exudate, prominent and widespread proliferation of (myo) fibroblasts, formation of new connective tissue and adhesions between tendon, paratenon, and the crural fascia [27].

\section{Insertional Achilles tendinopathy}

Insertional Achilles tendinopathy is located at the insertion of the Achilles tendon onto the calcaneus, possibly with the formation of bone spurs and calcifications in the tendon proper at the insertion site. Patients complain of pain, stiffness and sometimes (a solid) swelling. On physical examination, the tendon insertion (at the mid-portion of the posterior aspect of the calcaneus) is painful. A swelling may be visible and a bony spur may be palpable. Histopathologically, there is ossification of enthesial fibrocartilage, and 
sometimes small tendon tears occurring at the tendon-bone junction [35].

\section{Retrocalcaneal bursitis}

An inflammation of the bursa in the recess between the anterior inferior side of the Achilles tendon and the posterosuperior aspect of the calcaneus (retrocalcaneal recess) results in a visible and painful soft tissue swelling, medial and lateral to the Achilles tendon at the level of the posterosuperior calcaneus. Frequently, a postero-superior calcaneal prominence can be identified at plain radiography. Histopathologically, the fibro-cartilaginous bursal walls show degeneration and/or calcification, with hypertrophy of the synovial infoldings and accumulation of fluid in the bursa itself [41]. Alternatively, the bursa may be primarily involved by inflammatory or infectious bursitis due to an inflammatory arthropathy.

\section{Superficial calcaneal bursitis}

An inflammation of the bursa located between a calcaneal prominence or the Achilles tendon and the skin resulting in a visible, painful, solid swelling and discoloration of the skin. It is most often located at the postero-lateral aspect of the calcaneus. It is frequently associated with shoes with a rigid posterior portion. The Achilles tendon is usually not involved, however. Histopathologically, the subcutaneous bursa is an adventitious bursa, which is acquired after birth, and develops in response to friction. It is lined by hypertrophic synovial tissue and fluid. A superficial calcaneal bursitis can be further specified by its location, i.e. posterior, postero-lateral, or postero-medial.

Achilles tendinopathy and paratendinopathy often coexist. Retro-calcaneal bursitis is often seen in combination with insertional tendinopathy. Other combinations are possible, but occur less frequently.

\section{Conclusion}

An inconsistent and erroneous change in nomenclature of disorders of the Achilles tendon throughout the years has resulted in a large pool of confusing definitions and terms. A uniform and clear terminology is necessary for proper research, diagnostics and treatment. Proposed are new definitions, based on the anatomic location, symptoms, clinical findings and histopathology. In addition it is proposed that Haglund's disease, Haglund's syndrome, Haglund's deformity, pump bump (calcaneus altus; high prow heels; knobbly heels; cucumber heel), tendinitis are no longer used.
One of the following, depending on pathology, should be used instead: Mid-portion Achilles tendinopathy; Achilles paratendinopathy; insertional Achilles tendinopathy; retrocalcaneal bursitis and superficial calcaneal bursitis.

Open Access This article is distributed under the terms of the Creative Commons Attribution Noncommercial License which permits any noncommercial use, distribution, and reproduction in any medium, provided the original author(s) and source are credited.

\section{References}

1. Albert E (1893) Achillodynie. Wien Med Presse 34:41-43

2. Baracz V (1906) Tendonitis achillea arthritica als eine besondere Form der Achillessehnenerkrankung. Zcntrafbt Chir

3. Biyani A, Jones DA (1993) Results of excision of calcaneal prominence. Acta Orthop Belg 59:45-49

4. Brunner J, Anderson J, O'Malley M, Bohne W, Deland J, Kennedy J (2005) Physician and patient based outcomes following surgical resection of Haglund's deformity. Acta Orthop Belg 71:718-723

5. Caffey J (1962) Pediatric X-ray diagnosis. Year Book Medical, Chicago

6. Clain MR, Baxter DE (1992) Achilles tendinitis. Foot Ankle 13:482-487

7. Dickinson PH, Coutts MB, Woodward EP, Handler D (1966) Tendo Achillis bursitis. Report of twenty-one cases. J Bone Joint Surg Am 48:77-81

8. Federative Committee on Anatomical Terminology (1998) Terminologia anatomica. Thieme, New York, p 45

9. Fry HJH (1986) Overuse syndrome, alias tenosynovitis/tendinitis: the terminological hoax. Plast Recons Surg 78:414-417

10. Haglund P (1928) Beitrag zur Klinik der Achillessehne. Zeitschr Orthop Chir 49:49-58

11. Harris CA, Peduto AJ (2006) Achilles tendon imaging. Australas Radiol 50:513-525

12. Jerosch J, Nasef NM (2003) Endoscopic calcaneoplasty-rationale, surgical technique, and early results: a preliminary report. Knee Surg Sports Traumatol Arthrosc 11:190-195

13. Jerosch J, Schunck J, Sokkar SH (2007) Endoscopic calcaneoplasty (ECP) as a surgical treatment of Haglund's syndrome. Knee Surg Sports Traumatol Arthrosc 15:927-934

14. Kannus P, Jozsa L (1991) Histopathological changes preceding spontaneous rupture of a tendon. A controlled study of 891 patients. J Bone Joint Surg Am 73:1507-1525

15. Khan KM, Bonar F, Desmond PM, Cook JL, Young DA, Visentini PJ, Fehrmann MW, Kiss ZS, O'Brien PA, Harcourt PR, Dowling RJ, O'Sullivan RM, Crichton KJ, Tress BM, Wark JD (1996) Patellar tendinosis (jumper's knee): findings at histopathologic examination, US, and MR imaging. Victorian institute of sport tendon study group. Radiology 200:821-827

16. Kirkup J (1988) Mythology and History. In: Helal B, Wilson D (eds) The foot. Churchill Livingstone, London, pp 1-8

17. Kirmission E (1884) Cellulite peritendineuse du tendon d'Achille. Arch Gen Med 1:100-105

18. Le TA, Joseph PM (1991) Common exostectomies of the rearfoot. Clin Podiatr Med Surg 8:601-623

19. Leitze Z, Sella EJ, Aversa JM (2003) Endoscopic decompression of the retrocalcaneal space. J Bone Joint Surg Am 85:1488-1496

20. Lipscomb PR (1950) Tendons: nonsuppurative tenosynovitis and paratendinitis. Instr Course Lect 7:254-261 
21. Lohrer H, Nauck T, Dorn NV, Konerding MA (2006) Comparison of endoscopic and open resection for Haglund tuberosity in a cadaver study. Foot Ankle Int 27:445-450

22. Ly JQ, Bui-Mansfield LT (2004) Anatomy of and abnormalities associated with Kager's fat Pad. AJR Am J Roentgenol $182: 147-154$

23. Maffulli N, Khan KM, Puddu G (1998) Overuse tendon conditions: time to change a confusing terminology. Arthroscopy 14:840-843

24. Movin T, Kristoffersen-Wiberg M, Shalabi A, Gad A, Aspelin P, Rolf C (1998) Intratendinous alterations as imaged by ultrasound and contrast medium-enhanced magnetic resonance in chronic achillodynia. Foot Ankle Int 19:311-317

25. Nielson AL (1921) Diagnostic and therapeutic point in retrocalcanean bursitis. J Am Med Assoc 77:463

26. Ortmann FW, McBryde AM (2007) Endoscopic bony and softtissue decompression of the retrocalcaneal space for the treatment of Haglund deformity and retrocalcaneal bursitis. Foot Ankle Int 28:149-153

27. Paavola M, Jarvinen TA (2005) Paratendinopathy. Foot Ankle Clin 10:279-292

28. Painter CF (1898) Inflammation of the post-calcaneal bursa associated with exostosis. J Bone Joint Surg Am. 11(s1):169-180

29. Pavlov H, Heneghan MA, Hersh A, Goldman AB, Vigorita V (1982) The Haglund syndrome: initial and differential diagnosis. Radiology 144:83-88

30. Perugia L, Ippolitio E, Postacchini F (1976) A new approach to the pathology, clinical features and treatment of stress tendinopathy of the Achilles tendon. Ital J Orthop Traumatol 2:5-21
31. Puddu G, Ippolito E, Postacchini F (1976) A classification of Achilles tendon disease. Am J Sports Med 4:145-150

32. Raynal E (1883) Cellulite peritendineuse du tendon d'Achille. Arch Gen Med 11:677-689

33. Reinherz RP, Smith BA, Henning KE (1990) Understanding the pathologic Haglund's deformity. J Foot Surg 29:432-435

34. Rössler A (1895) Zur Kenntniss der Achillodynie. Deutsch Ztschr f Chir 52:274-291

35. Rufai A, Ralphs JR, Benjamin M (1995) Structure and histopathology of the insertional region of the human Achilles tendon. J Orthop Res 13:585-593

36. Schanz A (1905) Eine typische Erkrankung der Achillessehne. Zentralblatt für Chirurgie 32:1289-1291

37. Schunck J, Jerosch J (2005) Operative treatment of Haglund's syndrome. Basics, indications, procedures, surgical techniques, results and problems. Foot Ankle Surg 11:123-130

38. Sella EJ, Caminear DS, McLarney EA (1997) Haglund's syndrome. J Foot Ankle Surg 37:110-114

39. Smith DC (1960) Tendinitis- or peri tendinitis. BMJ 5183:1429

40. Sorosky B, Press J, Plastaras C, Rittenberg J (2004) The practical management of Achilles tendinopathy. Clin J Sport Med 14:40-44

41. Stephens MM (1994) Haglund's deformity and retrocalcaneal bursitis. Orthop Clin North Am 25:41-46

42. Vega MR, Cavolo DJ, Green RM, Cohen RS (1984) Haglund's deformity. J Am Podiatry Assoc 74:129-135 